\title{
Neo-oogenesis: Has its existence been proven?
}

\author{
Neo-oogenezi: Varlığı kanıtlandı mı?
}

\author{
Önder Çelik, Ebru Çelik, Ilgın Türkçüoğlu \\ Department of Obstetrics and Gynecology, Faculty of Medicine, Inönü University, Malatya, Turkey
}

\section{Introduction}

It was long believed that mammals are born with a fixed number of primordial follicles, each of which encloses an oocyte arrested at the diplotene step of meiotic prophase. Arising at or after birth, small numbers of primordial follicles become activated each day and enter a folliculogenic growth phase during which follicles either degenerate by atresia or complete maturation, resulting in ovulation (1-7). The reserve of follicles is claimed to continue depletion by the process of atresia throughout adulthood to the point of exhaustion around menopausal age, driving ovarian failure $(8,9)$.

Recently, the work of Johnson et al challenged the half century old dogma that the primordial follicle pool cannot be replenished after birth (10). Since then, the concept of neo-oogenesis has been a subject of vigorous experimentation and debate. Existing and challenging developments in female reproductive biology have led to a growing body of evidence that the ovarian follicle pool may be replenished during adult life.

\section{Evidence of Neo-ogenesis:}

The idea of a follicle arising from the surface epithelial cells of a postnatal mouse ovary was suggested as early as 1917 by Kingery (11). Recently, Kerr et al. reported a finding similar to the previous study showing that, consequent to a marked depletion of follicles and oocytes during the first postnatal week, the mean primordial follicle numbers per ovary, measured by using unbiased and assumption free stereological methods, remained constant and stable in the subsequent 13 weeks up to day 100 of age in C57BL/6 female mice, and their recruitment into the population of mature follicles was associated with no significant decay in the total numbers of all healthy follicles over the same period (12). The first demonstration of the isolation of germ-line stem cells (GSC) carrying a green fluorescent protein reporter gene from adult mouse ovaries that produce spontaneously component oocyte has challenged the classical belief (13). In 2004, an innovative study showed that the mouse ovary has an ability to produce new oocytes and follicles from GSC present in the ovarian surface epithelium after their destruction (10). Additionally, they reported the presence of presumptive mitotically active GSC, expressing the germ cell specific VASA protein, in or proximal to the OSE of juvenile and adult mice. However, some discordance in the rate of follicle loss versus follicle atresia in the neonatal ovaries and adult ovaries make it unlikely, in the opinion of the authors themselves that these cells can represent adult GCS. Based on the previous study, the same group also proposed the possibility of an extra gonadal source of germ cells in adult mice. The existence of ovarian primordial cells was depleted, and subsequently OSE cells were revoked in favor of bone marrow and peripheral blood cells as the derivation of newly formed oocyte-containing primordial follicles (14). In turn, a subsequent study demonstrated that, in a parabiotic model, no developmentally component oocytes derived from blood born progenitor germ were produced after bone marrow transplantation (15). Some concerns were expresed in this study that each used only two mice and a total of seven ovulated eggs or fewer were retrieved and examined. Indeed, a subsequent study has provided surprising insight into the presence of germ stem cells in the OSE of postmenopausal women. In this study, the isolation of rare putative stem cells with germ-line characteristics in the OSE of post-menopausal human ovaries devoid of oocytes was documented. Further, these cells have the ability to spontaneously form oocytes or oocyte-like cells and also could undergo pathogenetic development to generate blastocyst-like structures in vitro under certain conditions (16). In 2009, we demonstrated successfully developed ovarian cells and possible follicular structures by using porcine intestinal submucosa to reconstruct an ovarian defect. In addition, noticeable PCNA staining was found in oocytes arrested in the meitotic stage (17).

A recent case report somewhat contradicts the claim that precursors in peripheral blood may produce new functional germ cells; genetic analysis of a single offspring conceived by a female patient with Fanconi anemia who received bone marrow transplantation from an unrelated donor after a chemotherapy protocol along with thoraco-abdominal irradiation. Analysis of polymorphic microsatellites revealed a genetic link between the daughter and mother, but not with the donor. Based on this finding, the authors stated that unaccomplished depletion of the ovarian follicle pool,not the

Address for Correspondence: Önder Çelik, Department of Obstetrics and Gynecology, Faculty of Medicine, İnönü University, Turgut Özal Medical Center, Elazı̆̆ Road 8th,

Malatya, Turkey Phone: +90 5335130373 e.mail: oncelik@inonu.edu.tr

(C) Copyright 2011 by the Turkish-German Gynecological Education and Research Foundation - Available online at www.jtgga.org doi:10.5152/jtgga.2011.64 
transplantation of BM derived GSC, could be the reason for an improvement of fertility (18). Nonetheless, it is noteworthy that the capacity of the ovarian follicle reserve was not evaluated prior and subsequent to the BMT.

In parallel to continued studies into the regulation and function of germ stem cell in mouse ovaries, attempts are required to demonstrate the presence of a comparable population of GSC in human ovaries. However, the study aiming to demonstrate expression of SCP3 marker for meiosis in adult human ovarian tissue failed, in contrast to fetal ovary controls (19). The authors concluded, "If postnatal oogenesis is confirmed in mice, then this species would represent an exception to the rule that neooogenesis does not occur in adults". The inability of Liu et al. to detect the early oocyte marker, NOBOX, in their adult ovary samples is the major limitation despite being inconsistent with previously reported abundant expression of NOBOX in adult human ovaries. It is significant that SPC3 expressions also were detected in all of their adult human ovaries, even from a patient at 53 years of age. Moreover, Liu et al. themselves underscore the possible lack of functional conservation of genes claimed to be meiosis-specific from animal studies, concluding from their gene expression survey that MLH1, MSH5 and REC8 are not meiotic specific in humans. The authors did not determine either oogonia or oogonium-like cells expressing PCNA in the tunica albuginea and OSE among 231 sections from seven adult ovaries; in addition, their method for detection of oogonia or oogonium-like cells is ambiguous.

Of note, Niikura et al. demonstrated high expression of the premeiotic marker Stra8 and Daz1 in the ovary of aged female mice despite the absence of oocytes (20). Moreover, by grafting ovarian tissue harvested from an aged female germline specific GFP-expressing mice (PE-Oct4-Gfp or TgOG2 transgenic) into the ovarian bursal sac of young adult-type female recipients, a small number of GFP-positive germ cells, as immature follicles and co-expressing the primordial oocyte marker NOBOX, were detected. However, the number of immature follicles in the ovary of the young adult mouse, exposed directly to an aged systemic environment, was decreased. Further, this finding supports the concept that the rapid deterioration of follicles mostly involves impaired oocyte renewal rather than accelerated loss. In keeping with previous studies (21), Zou et al. established ovarian cells within the ovarian surface epithelium (OSE) that were double-positive for Mouse Vasa Homolog (MVH) and 5'-bromodeoxyuridine (BrDU) incorporation. High telomerase activity was detected in these cells when transplanted into females, giving rise to offspring that carried the signal. Recently, Pacchiarotti et al further illustrated the validation of cell lines as ovarian germline stem cells. The authors reported the isolation of cells containing the putative stem cells from the OSE of neonatal mice of the TgOG2. Likewise, these cells were presented from formation of "embryonic bodies" containing differentiated derivatives of the three germ layers and production of early stage of oocytes during culture (22).

\section{Conclusion}

The question of whether germ line stem cells exist in ovaries of humans should be actively addressed. This issue fascinates scientists involved in support offspring production and quality of life improvements in aged women. The view of neo-oogenesis in mammalian species is still controversial. There is growing evidence established in in vitro studies concerning the existence of putative GCS within adult mammalian ovaries, including humans. It may be possible that a small number of PGCs/ oogonia or PGC-derived undifferentiated cells with GSC characteristics remain in the postnatal and adult ovary, and under certain conditions may resume mitosis, enter meiosis and give rise to oocytes. However, further studies to provide evidence favoring germ cell proliferation and oocyte renewal in adult human ovaries are needed.

\section{References}

1. Zuckerman S. The number of oocytes in the mature ovary. Rec Prog Horm Res 1951; 6: 63-109.

2. Peters H. The development of the mouse ovary from birth to maturity. Acta Endocrinol (Copenh) 1969; 62: 98-116.

3. Albertin DF. Micromanagement of the ovarian follicle reserve-do stem cells play into the ledger? Reproduction 2004; 127: 513-4. [CrossRef]

4. Gosden RG. Germline stem cells in the postnatal ovary: is the ovary more like a testis? Hum Reprod Update 2004; 10: 193-5. [CrossRef]

5. Greenfeld C, Flaws JA. Renewed debate over post- natal oogenesis in the mammalian ovary. Bioessays 2004; 26: 829-32. [CrossRef]

6. Telfer EE. Germline stem cells in the postnatal mammalian ovary: a phenomenon of prosimian primates and mice? Reprod Biol Endocrinol 2004; 2: 24. [CrossRef]

7. Telfer EE, Gosden RG, Byskov AG, Spears N, Albertini D, Andersen $\mathrm{CY}$, et al. On regenerating the ovary and generating controversy. Cell 2005; 122: 821-2. [CrossRef]

8. Gosden RG, Laing SC, Felicio LS, Nelson JF, Finch CE. Imminent oocyte exhaustion and reduced follicular recruitment mark the transition to acyclicity in aging C57BL/6J mice. Biol Reprod 1983; 28: 255-60. [CrossRef]

9. Richardson SJ, Senikas V, Nelson JF. Follicular depletion during the menopausal transition: evidence for accelerated loss and ultimate exhaustion. J Clin Endocrinol Metab 1987; 65: 1231-7. [CrossRef]

10. Johnson J, Canning J, Kaneko T, Pru JK, Tilly JL. Germline stem cells and follicular renewal in the postnatal mammalian ovary. Nature 2004; 428: 145-50. [CrossRef]

11. Kingery HM. Oogenesis in the white mouse. J Morphol 1917; 30: 261-316. [CrossRef]

12. Kerr JB, Duckett R, Myers M, Britt KL, Mladenovska T, Findlay JK. Quantification of healthy follicles in the neonatal and adult mouse ovary: evidence for maintenance of primordial follicle supply. Reproduction 2006; 132: 95-109. [CrossRef]

13. Hübner K, Fuhrmann G, Christenson LK, Kehler J, Reinbold R, De La Fuente R. Derivation of oocytes from mouse embryonic stem cells. Science 2003; 300: 1251-6. [CrossRef]

14. Johnson J, Bagley J, Skaznik-Wikiel M, Lee HJ, Adams GB, Niikura $\mathrm{Y}$, et al. Oocyte generation in adult mammalian ovaries by putative germ cells derived from bone marrow and peripheral blood. Cell 2005; 122: 303-15. [CrossRef]

15. Eggan K, Jurga S, Gosden R, Min IM, Wagers AJ. Ovulated oocytes in adult mice derive from non-circulating germ cells. Nature 2006; 441: 1109-14. [CrossRef]

16. Virant-Klun I, Rozman P, Cvjeticanin B, Vrtacnik-Bokal E, Novakovic S, Rülicke T. Parthenogenetic embryo-like structures in the human ovarian surface epithelium cell culture in postmenopausal women with no naturally present follicles and oocytes. Stem Cells Dev 2009; 18: 137-49. [CrossRef] 
17. Celik O, Esrefoglu M, Hascalik S, Gul M, Tagluk ME, Elter K, et al. Use of porcine small intestinal submucosa to reconstruct an ovarian defect. Int J Gynecol Obstet 2009; 106: 218-22. [CrossRef]

18. Veitia RA, Gluckman E, Fellous M, Soulier J. Recovery of fertility after chemotherapy, irradiation and bone marrow allograft: further evidence against massive oocyte regeneration by bone marrow-derived germline stem cells. Stem Cells 2007; 25: 1334-5. [CrossRef]

19. Liu Y, Wu C, Lyu Q, Yang D, Albertini DF, Keefe DL, et al. Germline stem cells and neo-oogenesis in the adult human ovary. Dev Biol 2007; 306: 112-20. [CrossRef]
20. Niikura Y, Niikura T, Tilly JL. Aged mouse ovaries possess rare premeiotic germ cells that can generate oocytes following transplantation into a young host environment. Aging (Albany NY) 2009; 1: 971-8.

21. Zou K, Yuan Z, Yang Z, Luo H, Sun K, Zhou L, et al. Production of offspring from a germline stem cell line derived from neonatal ovaries. Nature Cell Biol 2009; 11: 631-6. [CrossRef]

22. Pacchiarotti J, Maki C, Ramos T, Marh J, Howerton K, Wong J, et al. Differentiation potential of germ line stem cells derived from the postnatal mouse ovary. Differentiation 2010; 79: 159-70. [CrossRef]

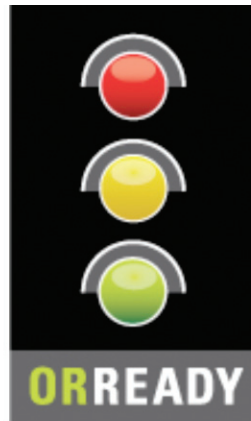

We are ORReady and support operating room safety to improve patient outcome.
ORReady is a worldwide, multi-Specialty initiative to encourage steps that are known to improve surgical outcomes and save lives.

If the suggested guidelines, which include Check Lists, Time Outs and Warm Ups are followed routinely, we estimate that Six Million patients around the world could have better outcomes.

Find out how your department and hospital can be ORReady and improve outcomes at http://www.sls.org/outcome 